\title{
Foresight-driven Approach to Support the Proactive Adaptation of Future Sustainability Related Regulatory Frameworks: European Port Cluster Study
}

\author{
Harri Pyykkö1 ${ }^{*}$, Ville Hinkka1 ${ }^{1}$, Tuomo Uotila², Rosa Palmgren ${ }^{1}$ \\ ${ }^{1}$ VTT Technical Research Centre of Finland Ltd., FI-02044 Espoo, Finland \\ ${ }^{2}$ LUT University, FI-15210 Lahti, Finland
}

\begin{abstract}
Seaports (hereafter "ports") within the European Union are facing increasingly restrictive regulation in the near future from various sources driven by climate change prevention and public opinion supporting "green" values. Ports are complex hubs for maritime transportation systems and global supply chains, as well as an integral part of critical national infrastructures. However, they are also significant individual sources of harmful emissions, and their involvement is crucial to reducing transportation-related environmental impacts. To meet future regulatory requirements, stakeholders will need to find ways to align their policies accordingly and create long-term pathways toward these ambitious targets. The empirical case study presented in this paper among European Port Cluster (EPC) stakeholders distinctly reflects the mounting importance of environmental policies and the need for further preparative measures for meeting future demands. This paper emphasizes the intensified impact of forthcoming regulation on existing business models in the EPC and contributes a foresight-based framework to approaching this issue systematically. The adoption of future-oriented regulation is a non-linear, potentially disruptive, and complex foresight process that requires each stakeholder to formulate their own strategic pathway toward a target-seeking scenario. Changing direction from the status quo toward sustainability also requires a strong commitment beyond mere regulatory compliance.
\end{abstract}

Keywords: Backcasting; Emissions; Port; Regulation; Sustainability

\section{Introduction}

Seaborne transportation is a vitally important part of global trade, and within the European Union (EU) region, there are up to 1,200 active seaports (hereafter "ports"; ENISA, 2019). As ports handle more than $80 \%$ of global trade, they are also considered a critical national infrastructure (UNCTAD, 2018). However, globally, significant amounts of harmful emissions caused by port operations, as well as by vessels, trucks, and trains visiting the ports, create air pollution and jeopardize the well-being of nearby inhabitants. In addition, greenhouse gas (GHG) emissions are accelerating climate change (UNEP, 2021). An extensive sustainability survey of 36 ports in North America, Europe, and the AsiaPacific (Hossain et al., 2021) concluded that European ports are slightly ahead in terms of sustainability progress, but that there is an urgent need for rapid improvement in adopting actions that address climate change.

Climate change and related environmental challenges have been identified as the most

*Corresponding author's email: harri.pyykko@vtt.fi, Tel.: +358-400-344297

doi: 10.14716/ijtech.v12i5.5252 
essential megatrends that predominantly affect the future development of all freight transportation systems (Maraš et al., 2019). There is already extensive empirical research data available (e.g., Oeder et al., 2015) that demonstrate how harmful fossil fuels are to public health and the environment when used within the port infrastructure (PI).

The business-as-usual approach in the European Port Cluster (EPC) is evidently not a sufficient pathway (Laffineur, 2012), and a growing body of scholars (e.g., Bjerkan and Seter, 2019; Berawi, 2021) are highlighting the requirement for diverse research and new initiatives to support actions toward sustainability. Operational activities within the PI have traditionally been considered very energy-intensive (Pavlic et al., 2014). Moreover, improved energy efficiency is considered a vital effort toward the mitigation of port emissions, which requires large-scale investments in new and more state-of-the-art equipment (Ganda, 2019), as well as the utilization of alternative energy sources (Pavlic et al., 2014). Table 1 summarizes the complexity of governing emission sources with respect to multiple different stakeholders operating within the PI and coastal areas. Each stakeholder has a certain influence on the overall emissions occurring within the PI, and their combined emission mitigation efforts define the overall results (Lai et al., 2013).

Although regulation is recognized as a strong driver of sustainability transition (ST), there are also major hindrances, such as organizational path dependencies (e.g., Teece et al., 1997) and various lock-in effects (Markard et al., 2012), resulting primarily from the high capital intensity distinctive of transport systems (Bernardino et al., 2015). Table 1 shows how regulation related to ports developed between 2013 and 2021 in the EU. In 2021, the EU set a target of making the continent carbon-neutral by 2050 and cutting $\mathrm{CO}_{2}$ emissions by $55 \%$ by 2030 compared with the levels in 1990 . However, the trend leading to this decision was already visible in other regulations since 2013. In theory, this extensive timeframe allowed actors to adjust their existing business models to meet the upcoming regulatory requirements of carbon neutrality several years before the actual decision was made in 2021. However, the research literature (e.g., Banerjee, 2001) proposes that due to the complexity of the topic, regulation often does not have direct causal impacts and can result in inadvertent outcomes despite the original purpose (Soria-Lara and Banister, 2018).

Table 1 Regulatory framework applicable within the port cluster in the EU

\begin{tabular}{lcc}
\hline \multicolumn{1}{c}{ Regulatory Initiative } & Year & Reference \\
\hline $\begin{array}{l}\text { As a part of its "Ports: an engine for growth" report, the European } \\
\text { Commission suggested that ports become more active in improving the } \\
\text { environmental image of waterborne transport by implementing an } \\
\text { infrastructure-charging system that favors vessels fulfilling predefined } \\
\text { environmental standards. }\end{array}$ & 2013 & $\begin{array}{c}\text { European } \\
\text { Commission, 2013 }\end{array}$ \\
$\begin{array}{l}\text { According to the circular economy approach, waste can be turned into a } \\
\text { resource by reusing, repairing, refurbishing, and recycling existing } \\
\text { materials and products. }\end{array}$ & 2014 & $\begin{array}{c}\text { European } \\
\text { Commission, 2014 }\end{array}$ \\
$\begin{array}{l}\text { European Commission has invited the member states and the European } \\
\text { maritime industry to work together toward the long-term objective of } \\
\text { "zero waste, zero emissions" in maritime transport. }\end{array}$ & 2016 & $\begin{array}{c}\text { European } \\
\text { Commission, 2016 }\end{array}$ \\
\hline $\begin{array}{l}\text { The EU strives to minimize its dependence on oil and to mitigate the } \\
\text { environmental impacts of transport. }\end{array}$ & 2017 & $\begin{array}{c}\text { European } \\
\text { Commission, 2017 }\end{array}$ \\
$\begin{array}{l}\text { EU and its member states to become a carbon-neutral region by 2050, } \\
\text { including a target of 55\% minimum reduction in GHG emissions by }\end{array}$ & 2020 & $\begin{array}{c}\text { European } \\
\text { 2030. }\end{array}$ \\
\hline $\begin{array}{l}\text { The European Green Deal regulatory framework has been approved. } \\
\text { The program's objective is for the continent to become carbon-neutral } \\
\text { by 2050. }\end{array}$ & 2021 & \begin{tabular}{c} 
Commission, 2020 \\
\hline
\end{tabular}
\end{tabular}


ST toward more sustainable port operations is a complex, potentially disruptive, and long-term process that requires new policies and innovative solutions (Pavlic et al., 2014), in addition to the ability of each involved stakeholder to plan ahead (Schrettle et al., 2014). However, there is evidence (e.g., Becker and Caldwell, 2015) that some notable decisions regarding sustainability within the port domain are still driven by short-term economic benefits rather than focusing on long-term planning toward sustainability and the future requirements of port operations. Hence, the use of foresight methods to formulate future scenarios has been recognized as a workable conceptual tool to systematically approach this issue (Berawi, 2016; Yashin et al., 2020). Foresight activities can also be utilized to provide decision-makers with information about different scenarios and to potentially visualize how passive approaches are in conflict with predominant insights about the future (McDonald et al., 2018). The objective of this paper is two-fold: (1) to analyze empirical survey results and research literature findings in order to reflect the findings against the upcoming regulatory framework; and (2) to review, align, and contextualize the most suitable foresight method in order to formulate a process framework model that would develop long-term sustainability-related regulatory adoption in the EPC.

\section{Methods}

This paper is a conceptual exploration of the research literature, providing insight into the role of upcoming environmental regulation as an external and future-oriented driver and as a normative scenario having an integral part in ST. The literature findings were analyzed qualitatively using a concept-driven approach (Schreier, 2014). We claim that foresight-related methods provide suitable tools to analyze how regulatory information is transformed into strategic knowledge, thereby allowing stakeholders to incorporate this knowledge into their strategies and formulate long-term and target-seeking pathways. Based on the literature review, further analysis was conducted to identify which particular elements of foresight methods contribute to the proposed future regulation adoption process (FRAP).

Empirical data were collected between June and October 2018 from EPC stakeholders connected to the COREALIS project (EU grant agreement No. 768994). The questionnaire results are presented in a public document (D.1.2: COREALIS, 2018). One of the authors participated in the questionnaire review and data collection and therefore had access to the raw data. These results were used to deepen our understanding of the responses presented in (D.1.2: COREALIS, 2018). The empirical data were used to reflect the companies' outlook on long-term ST to carbon-neutral operations in autumn 2018. Given that clear signs already existed that their operations would someday have to become carbon-neutral, one could assume that these companies had at least taken some steps to prepare for this ST by 2018. Consequently, the parts of the questionnaire dealing with initial preparations for ST were analyzed in detail. We assumed that the adoption of key performance indicators (KPIs) related to sustainability would be among the first signs of adopting operations that cause less $\mathrm{CO}_{2}$ emissions. Adoption of KPIs does not necessarily involve investments at this stage, but it does show a willingness to invest in these things in the future. Without KPIs, however, a company will never be able to understand how to achieve future targets related to carbon neutrality.

This paper aims to generate a process framework that hypothetically acts as the basis for organizational strategy. The proposed process framework should narrow the existing threshold among EPC stakeholders to proactively increase ST actions. Figure 1 demonstrates the research flow and research questions (RQ 1 \& RQ 2). 


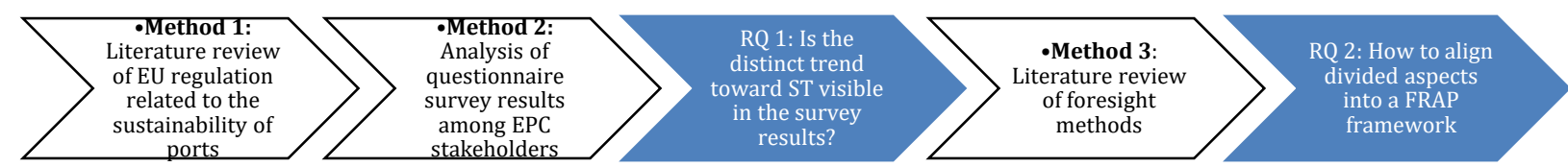

Figure 1 Presentation of the research flow

\subsection{Foresight Methods Supporting the Target-seeking Pathway}

Future scenarios are considered a functional method to underpin policies and lead the way toward sustainability (Fauré et al., 2017). Depending on the approach to the above questions, the scenario categories comprise predictive, explorative, and normative scenarios (Börjeson et al., 2006). The regulatory future can be considered normative, as there is a clear target ahead in the future; normative scenarios are also referred to as desirable futures (Vergragt and Quist, 2011). Fazey et al. (2016) emphasize that conceptualized foresighting pathways to support sustainability are tools to reinforce decision-makers' understanding. The pathway approach can describe the response style to specific issues as proactive, reactive, inactive, or business-as-usual (McDonald et al., 2019).

Table 2 Comparison of the suitability of common foresight methods

\begin{tabular}{ccc}
\hline Foresight method & Target-seeking pathway & Normative scenarios \\
\hline Trend extrapolations & & \\
Forecasting & $\mathrm{X}$ & $\mathrm{X}$ \\
\hline Strategic foresight & $\mathrm{X}$ & \\
\hline Backcasting &
\end{tabular}

As the regulatory future requires both a target-seeking pathway and a normative scenario approach, the most suitable foresighting method that fulfils both the criteria is backcasting (Table 2.). The idea of backcasting is to make the future more achievable by first envisioning and exploring the future that we want to have, and then looking at the opportunities and alternatives for pathways to achieve that future (Robinson et al., 2011). The definition of backcasting is formed as follows: "generating a desirable future, and then looking backwards from that future to the present in order to strategize and to plan how it could be achieved" (Vergragt and Quist, 2011). The backcasting process can be divided into different process phases: the "visioning phase," "policy packaging," and the "appraisal phase." The visioning phase is about looking at how the future could be envisioned as naturally aiming toward a contrast to the current ways in which businesses work. The policy packaging phase identifies the possible policies that could help in reaching the future, but also sets timetables for these policies and for practical implementation. Lastly, the third stage is the appraisal phase, exploring the broad picture of the impact in terms of the sustainability dimensions (Soria-Laria and Banister, 2018).

\subsection{Transformation of Regulatory Information to Transition Pathway}

Sotarauta et al. (2002) highlight that the foresight process needs to align deeply with the organizational structures and transform information into organizational knowledge, prior to proceeding with the creation of future scenarios and pathways. Consequently, it is essential for a successful and long-term FRAP to have a comprehensive understanding of what forthcoming regulation signifies from the specific point of view of an individual organization. Digitalization has enabled simple access to information databases where various types of trend analysis and specific information are easily available. Collecting the information, scanning the specific environment, trend scoping, and summarizing this for 
further future-oriented decision-making is a relevant front-end stage of a foresight process (Horton, 1999; Marchand, 2000). However, information such as announcements on forthcoming regulation is considered passive by nature, whereas knowledge is more of a cognitive capability (Foray, 2006) that strives to comprehend contextual reasons and consequences (Teece and Pisano, 1994; Teece, 2000).

An organization's interaction with dynamic environments requires that organizations are capable of creating new knowledge in addition to processing new information and utilizing their knowledge (Nonaka, 1994). The accumulation of knowledge within an organization has positive impacts, generating new knowledge in terms of specific topics (Arthur, 1996; Storper, 1997). The assimilation of new knowledge deeper into organizational innovation processes and strategic planning has been noted as a critical factor in the absorptive capacity process (Zahra and George, 2002). Organizations with high absorptive capacity have almost inevitably adopted a proactive approach benefiting from structured knowledge accumulation (Cohen and Levinthal, 1990). Acknowledgement of a future-oriented approach, renewal capabilities, and adaptability to transformation processes have been identified as characteristics of successful organizational development (Ahmed, 1998). Producing new knowledge is gradually being considered important as organizations seek ways to meet forthcoming stringent emission-reduction targets (Schrettle et al., 2014).

\section{Results and Discussion}

\subsection{Empirical Survey of the European Port Cluster}

The questionnaire was sent to 1,346 General Data Protection Regulation (GDPR)compliant contacts of COREALIS project members involved with port stakeholders around Europe during the autumn of 2018. With 107 responses, the response rate was $7.9 \%$. However, due to incomplete and missing responses for questions reflecting the adoption of climate change-related KPIs, only $68.2 \%$ of the responses were usable. Hence, the final number of responses analyzed in this paper was limited to 73. Based on the questionnaire, the respondents considered environmental issues important, giving the importance of environmental policy for their business a score of 4.21 on a scale of 1 to 5 , even if only $61 \%$ of them indicated that environmental policies were applicable to their business area with the port.

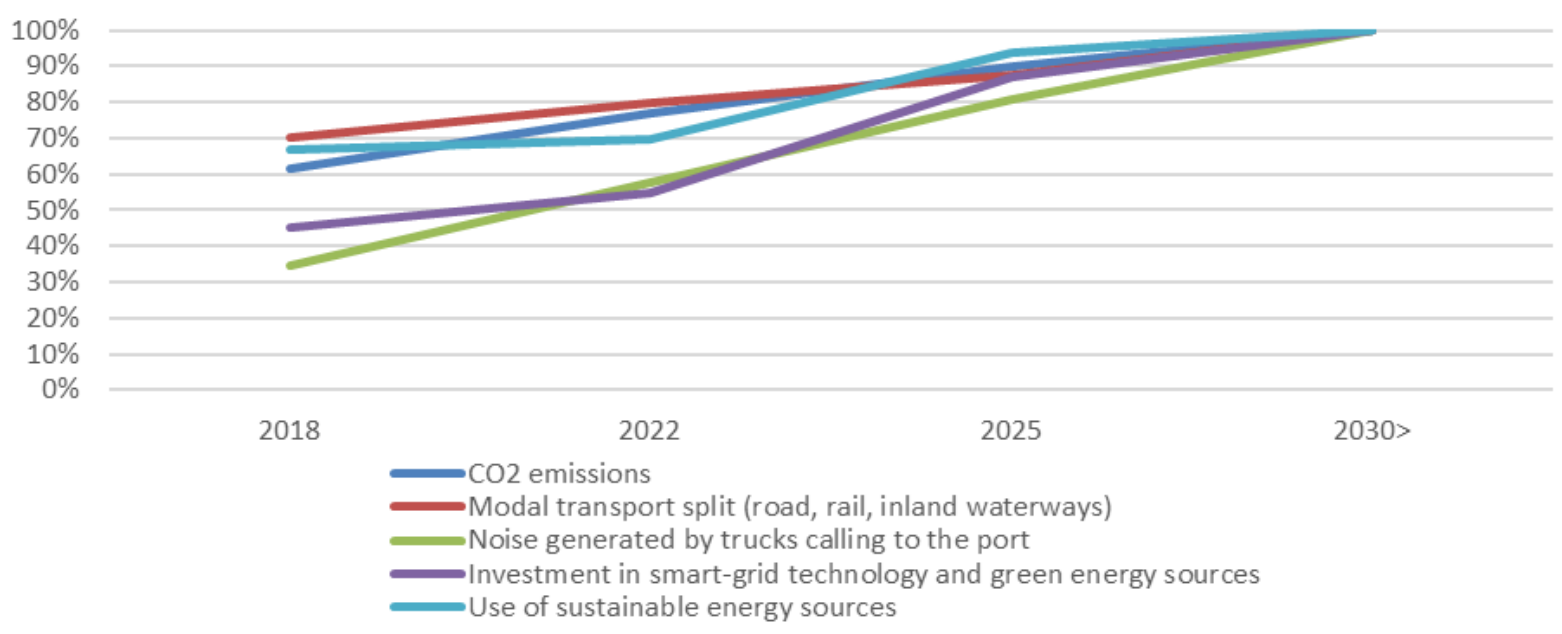

Figure 2 The respondents' attempts to adopt climate-change-related KPIs over time. In each KPI, only those respondents that have either adopted or are going to adopt the KPI are considered 
However, based on the questionnaire results, the respondents lacked any practical implementation of environmental policy in their operations. For example, only $51 \%$ of the companies had KPIs related to $\mathrm{CO}_{2}$ emissions and $49 \%$ had KPIs related to the use of sustainable energy sources in 2018.

Based on the questionnaire results, the respondents did not consider many climatechange-related KPIs to be relevant in 2018. For example, only 23\% of respondents considered $\mathrm{CO}_{2}$-emission-related KPIs important in 2018. Figure 2 presents the scenario when the organizations that are going to adopt climate-change-related KPIs are going to do that. In 2018, for example, $62 \%$ of the organizations that are going to adopt $\mathrm{CO}_{2}$-emissionsrelated KPIs have done it at the time when the questionnaire was performed; $77 \%$ of respondents believe that they will in 2022, 13\% will adopt them around 2025, and the rest $10 \%$ not until after 2030 . The respondents were also asked about KPIs related to the use of sustainable energy sources, investment in smart-grid technology and green energy sources, modal transport split, and noise generated by trucks calling to the port. In general, the responses for the use of sustainable energy sources and for modal transport split were rather similar to the responses for $\mathrm{CO}_{2}$ emissions. For the KPIs about the noise generated by trucks and about investment in smart-grid technology and green energy sources, the adoption rate is slower: in 2018, only 35\% had KPIs related to the former and $45 \%$ had KPIs related to latter.

\subsection{Proposed Future Regulatory Adoption Process Framework}

Several scholars (Robinson, 1990; Quist, 2007; Wiek and Iwaniec, 2014; Kishita et al. 2016) have recognized backcasting as a more feasible method, notably for approaching determined future visions, creating pathways toward desired future visions, and classifying what is required to achieve a specific future target. Hence, the proposed FRAP framework (Figure 3) is based on backcasting methodology, which presumably provides suitable elements to formulate a target-seeking ST pathway for stakeholders whose business models need to change, often drastically, due to upcoming regulation.

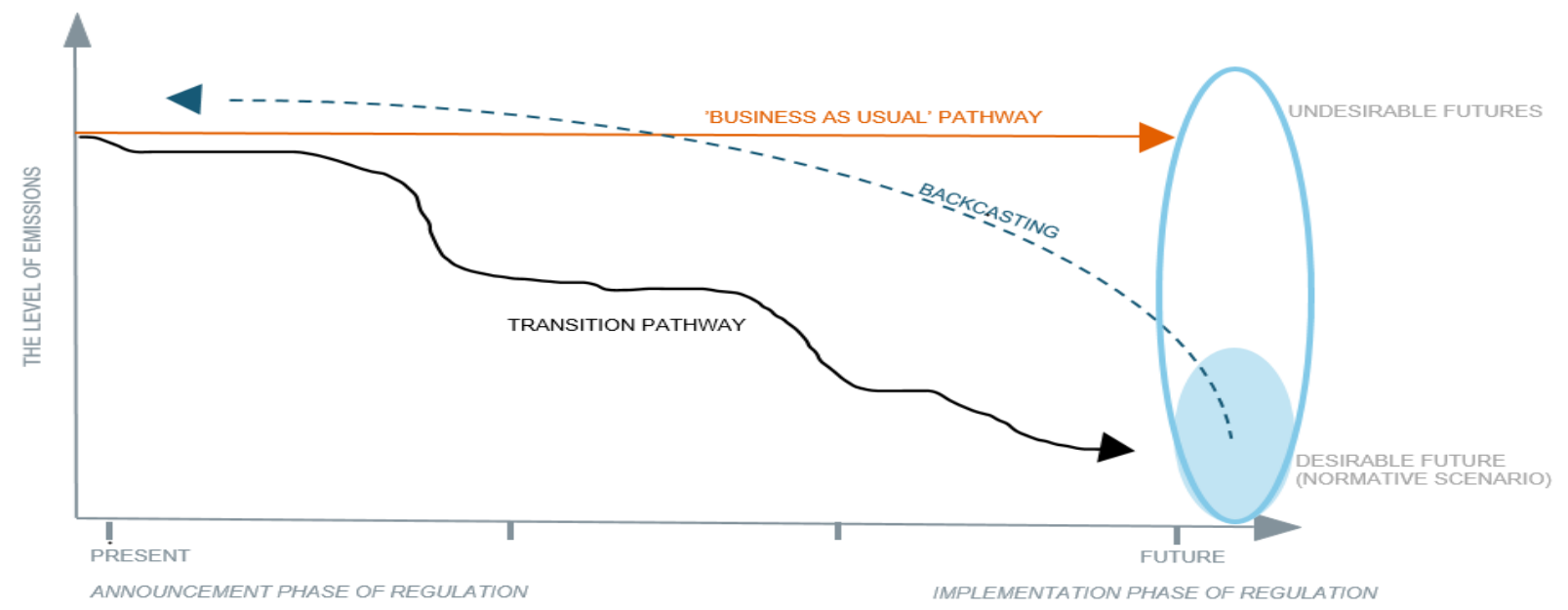

Figure 3 Proposed FRAP framework (adopted and modified from Quist, 2007; Kishita et al., 2016)

Continuous observation and situational awareness of the transition progress and reacting to deviations are crucial and can be monitored through measurable sustainability-related KPIs (Jakeman et al., 2008). The designed future scenarios are not considered as final outcomes but as workable tools to support organizational strategic processes (Bernardino et al., 2015). Intensified regulation toward emission mitigation within the EPC is having an impact on organizations' future strategies and business progression. As these organizations 
continually try to balance varying and often conflicting future demands, regulation-driven sustainability will unavoidably have to be incorporated into their decision-making processes. Once rapid ST toward more environmentally sustainable practices begins, it is likely to cause added expenses and decreasing profit margins over a certain period compared with organizations in the EPC that have not yet chosen a proactive approach toward future environmental demands (Min and Galle, 2001). It has also been highlighted (e.g., Carpender et al., 2018) that due to the importance of port and maritime clusters for global trade, environmental actions should not jeopardize the operability of these clusters at any stage. Therefore, well-planned proactive environmental actions are seen as a tool to gain strategic advantage by predicting future developments against organizations that are passive (Tay et al., 2015). Successful implementation requires that procedures and decisions supporting the ST process require a commitment from the whole organization (Hussain, 1999).

The proposed FRAP (Figure 3) consists of five phases:

1. Contextualization of the regulatory announcement and understanding its meaning as a normative future scenario affecting EPC stakeholders.

2. Constructing a vision of an organizationally desirable future in alignment with a normative regulatory scenario.

3. Generating a systematic scheme and potential milestones for the transition pathway toward the desirable future.

4. Incorporating the transition pathway into organizational strategies and decisionmaking processes.

5. Effectively measuring the pathway progression with well-designed KPIs.

\subsection{Proactive and Systematic Approach for a More Sustainable Future}

The potential contradiction with other development areas is causing trade-offs and disruptions to the existing business model, which can only be solved by incremental changes and breaking away from path dependencies. Proactive preparation for future demands and regulatory limitations is vital if organizations are to have the capability to formulate a pathway for their ST prior to such regulation coming into force. Incorporating environmental targets closely with organizational strategy and the capability to reform have been recognized as one of the key characteristics of a successful organization (Barr et al., 1992). An ignorant or reactive mindset toward regulation eventually puts tremendous pressure on an organization that may fear losing its competitive advantage, while a proactive organization will benefit down the road, thanks to its ongoing ST efforts (e.g., Schrettle et al., 2014). Based on the research literature (e.g., Hua et al., 2020), it is notable that some EPC stakeholder organizations are adopting sustainability-related actions for the mere purpose of regulatory compliance, while others have already adopted sustainability as one of their core values.

\section{Conclusions}

Based on the empirical survey and research literature findings, it is evident that the organizations within EPC need to accelerate their sustainability efforts in order to meet the upcoming regulatory framework. Due to the complexity and non-linear mechanisms involved, ambitious emission reduction goals can be achieved in a sustainable way only with long-term strategic planning and a proactive approach. This paper presented a contextualized backcasting-based foresight framework using a target-seeking approach as a novel conceptual contribution to tackle this complex issue. This paper further suggests that once EPC stakeholders implement sustainability governance-related tools similar to 
FRAP as a rigid part of their future strategies, they will support the generation of ST roadmaps and improve the identification of potential investment needs and major obstacles in advance.

\section{Acknowledgements}

The authors wish to acknowledge the "COREALIS" project, which has received funding from the European Union's Horizon 2020 research and innovation programme under grant agreement No. 768994. The content reflects solely the authors' view, and the EU is not responsible for any use of the information it contains.

\section{References}

Ahmed, P.K., 1998. Culture and Climate for Innovation. European Journal of Innovation Management, Volume 1(1), pp. 30-43

Arthur W.B., 1996. Increasing Returns and the New World of Business. Harvard Business Review, Volume 74(4), pp. 100-109

Banerjee, S.B., 2001. Managerial Perceptions of Corporate Environmentalism: Interpretations from Industry and Strategic Implications for Organizations. Journal of Management Studies, Volume 38(4), pp. 489-513

Barr, P.S., Stimbert, J.L., Huff, A.S., 1992. Cognitive Change, Strategic Action, and Organizational Renewal. Strategic Management Journal, Volume 13(S1), pp. 15-36

Becker, A., Caldwell, M.R., 2015. Stakeholder Perceptions of Seaport Resilience Strategies. Coastal Manage, Volume 43(1), pp. 1-34

Berawi, M.A., 2016. Accelerating Sustainable Infrastructure Development: Assuring Wellbeing and Ensuring Environmental Sustainability. International Journal of Technology, Volume 7(4), pp. 527-529

Berawi, M.A., 2021. Managing Cross-Sectoral Coordination in Accelerating the Sustainable Development Agenda. International Journal of Technology, Volume 12(2), pp. 228-231

Bernardino, J., Aggelakakis, A., Reichenbach, M., 2015. Transport Demand Evolution in Europe - Factors of Change, Scenarios and Challenges. European Journal of Futures Research, Volume 3(13), pp. 1-13

Bjerkan, K., Seter, H., 2019. Reviewing Tools and Technologies for Sustainable Ports: Does Research Enable Decision Making in Ports? Transportation Research, Part D, Transport and Environment, Volume 72, pp. 243-260

Börjeson, L., Höjer, M., Dreborg, KH., Ekvall, T., Finnvede, G., 2006. Scenario Types and Techniques: Towards a User's Guide. Futures, Volume 38, pp. 723-739

Carpender, A., Lozano, R., Sammalisto, K., Astner, L., 2018. Securing a Port's Future through Circular Economy: Experiences from the Port of Gävle in Contributing to Sustainability. Marine Pollution Bulletin, Volume 128, pp. 539-547

Cohen, W., Levinthal, D., 1990. Absorptive Capacity: A New Perspective on Learning and Innovation. Administrative Science Quarterly, Volume 35(1), pp. 128-152

D.1.2: COREALIS Personas and Stakeholder Classification. 2018. Available Online at https://www.corealis.eu/wp-content/uploads/2020/02/D.1.2-COREALIS-Personasand-Stakeholder-classification.pdf, Accessed on 9 August 2021

ENISA, 2019. Port Cybersecurity - The good practices for cybersecurity in the maritime sector, October 2019. Available Online at https://www.enisa.europa.eu/publications/port-cybersecurity-good-practices-forcybersecurity-in-the-maritime-sector, Accessed on 22 August 2021

European Commission, 2013. 'Ports: an engine for growth'. COM/2013/0295, 23.05.2013. 
European Commission, 2014. The circular economy: Connecting, creating and conserving value. Publication Office, Brussels

European Commission, 2016. COMMISSION STAFF WORKING DOCUMENT on the implementation of the EU Maritime Transport Strategy 2009-2018

European Commission, 2017. Study on differentiated port infrastructure charges to promote environmentally friendly maritime transport activities and sustainable transportation. CONTRACT MOVE/B3/2014-589/SI2.697889, FINAL REPORT

European Commission, 2020. Proposal for a REGULATION OF THE EUROPEAN PARLIAMENT AND OF THE COUNCIL establishing the framework for achieving climate neutrality and amending Regulation (EU) 2018/1999 (European Climate Law)

European Commission, 2021. Delivering the Green Deal

Fauré, E., Arushanyan, Y., Ekener, E. Miliutenko, S., Finnveden, G., 2017. Methods for Assessing Future Scenarios from a Sustainability Perspective. European Journal of Futures Research, Volume 5(17), pp. 1-20

Fazey, I., Russell, M.W., Lyon, C., Câmpeanu, C., Moug, P., Davies, T., 2016. Past and Future Adaptation Pathways. Climate and Development, Volume 8(1), pp. 26-44

Foray, D., 2006. The Economics of Knowledge. The MIT Press

Ganda, F., 2019. The Impact of Innovation and Technology Investments on Carbon Emissions in Selected Organization for Economic Co-Operation and Development Countries. Journal of Cleaner Production Research, Volume 217, pp. 469-483

Horton, A., 1999. A Simple Guide to Successful Foresight. Foresight, Volume 1(1), pp. 5-9

Hossain, T., Adams, M., Walker, T.R., 2021. Role of Sustainability in Global Seaports. Ocean \& Coastal Management, Volume 202, pp. 1-10

Hua, C., Chen, J., Wan, Z., Xu, L., Bai, Y., Zheng, T., Fei, Y., 2020. Evaluation and Governance of Green Development Practice of Port. Journal of Cleaner Production, Volume 249, https://doi.org/10.1016/j.jclepro.2019.119434

Hussain, S., 1999. The Ethics of Going Green: The Corporate Social Responsibility Debate. Business Strategy and the Environment, Volume 8(4), pp. 203-210

Jakeman, A., Voinov, A., Rizzoli., A., Chen, S., 2008. Environmental Modelling, Software and Decision support: State of the Art and New Perspective. Elsevier

Kishita, Y., Hara, K., Uwasu, M., Umeda, Y., 2016. Research Needs and Challenges Faced in Supporting Scenario Design in Sustainability Science: A Literature Review. Sustainability Science, Volume 11, pp. 331-347

Laffineur, L., 2012. Scheepvaartemissies in een Intertnationale en Europese context: Problemen en oplossingen, Anwerpen: Koninklijke Belgische Redersverening

Lai, K.H., Lun, Y.H.V., Wong, C.W.Y., Ngai, E.W.T., Cheng, T.C.E., 2013. Measures for Evaluating Green Shipping Practices. International Journal of Shipping Transport Logistics, Volume 3(2), pp. 217-235

Maraš, V., Bugarinović, M., Anoyrkati, E., Avarello A., 2019. Megatrends, a Way to Identify the Future Transport Challenges. In: Nathanail E., Karakikes I. (eds) Data Analytics: Paving the Way to Sustainable Urban Mobility. CSUM 2018. Advances in Intelligent Systems and Computing, pp. 223-232. Springer, Cham

Marchand, D.A., 2000. Competing with information. A Managers Guide to Creating business value with information content. John Wiley \& Sons Ltd, England. $342 \mathrm{~s}$

Markard, J., Raven, R., Truffer, B., 2012. Sustainability transitions: An Emerging Field of Research and its Prospects. Research Policy, Volume 41(6), pp. 955-967

McDonald, K.S., Hobday, A.J., Fulton, E.A., Thompson, P.A., 2018. Interdisciplinary Knowledge Exchange Across Scales in a Globally Changing Marine Environment. Global Change Biology, Volume 24(7), pp. 3039-3054 
McDonald, K.S., Hobday, A.J., Thompson, P.A., Lenton, A., Stephenson, R.L., Mapstone, B.D., Dutra, L.X.C., Bessey, C., Boschetti, F., Cvitanovic, C., Bulman, C.M., Fulton, E.A., Moeseneder, C.H., Pethybridge, H., Plagányi, E.E., Ingrid van Putten, E., Rothlisberg, P.C., 2019. Proactive, Reactive, and Inactive Pathways for Scientists in a Changing World. Earth's Future, Volume 7(2), pp. 60-73

Min, H., Galle, W., 2001. Green Purchasing Practices of US Firms. International Journal of Operations \& Production Management, Volume 21(9), pp. 1222-1238

Nonaka, I., 1994. A Dynamic Theory of Organizational Knowledge Creation. Organization Science, Volume 5(1), pp. 14-37

Oeder, S., Kanashova, T., Sippula, O., Sapcariu, S.C., Streibel, T., Arteaga-Salas, J.M., Passig, J., Dilger, M., Paur, H-R., Schlager, C., Mülhopt, S., Diabaté, S., Stengel, B., Rabe, R., Harndorf, H., Torvela, T., Jokiniemi, J.K., Hirvonen, M-R., Schmidt-Weber, C., Traidl-Hoffmann, C., BéruBé, K.A., Wlodarczyk, A.J., Prytherch, Z., Michalke, B., Krebs, T., Prévôt, A.S.H., Kelbg, M., Tiggesbäumker, J., Karg, E., Jakobi, G., Scholtes, S., Schnelle-Kreis, J., Lintelmann, J., Matuschek, G., Sklorz, M., Klingbeil, S., Orasche, J., Richthammer, P., Müller, L., Elsasser, M., Reda, A., Gröger, T., Weggler, B., Schwemer, T., Czech, H., Rüger, C.P., Abbaszade, G., Radischat, C., Hiller, K., Buters, J.T.M., Dittmar, G., Zimmermann, R., 2015. Particulate Matter from Both Heavy Fuel Oil and Diesel Fuel Shipping Emissions Show Strong Biological Effects on Human Lung Cells at Realistic and Comparable In Vitro Exposure Conditions, PLoS One, Volume 10(6), pp. 1-17

Pavlic, B., Cepak, F., Sucic, B., Peckaj, M., Kandus, B., 2014. Sustainable Port Infrastructure, Practical Implementation of the Green Port Concept AU. Thermal Science, Volume 18(3), pp. 935-948

Quist, J., 2007. Backcasting for a Sustainable Future: The Impact After 10 Years. Eburon Academic Publishers, Delft, Netherlands

Robinson, J., 1990. Futures Under Glass: A Recipe for People Who Hate to Predict. Futures Volume 22(8), pp. 820-842

Robinson, J., Burch, S., Talwar, S., O’Shea, M., Walsh, M., 2011, Envisioning Sustainability: Recent Progress in the use of Participatory Backcasting Approaches for Sustainability Research. Technological Forecasting \& Social Change, Volume 78(5), pp. 756-768

Schreier, M., 2014. Qualitative Content Analysis. Sage Handbook of Qualitative Data Analysis. SAGE Publications ltd

Schrettle, S., Hinz, A., Scherrer-Rathje, M., Friedli, T., 2014. Turning Sustainability into Action: Explaining Firms' Sustainability Efforts and Their Impact on Firm Performance. International Journal of Production Economics, Volume 147(Part A), pp. 73-84

Soria-Lara, J.A., Banister, D., 2018. Evaluating the Impacts of Transport Backcasting Scenarios with Multi-Criteria Analysis. Transportation Research Part A: Policy and Practice, Volume 110, pp. 26-37

Soria-Lara, J.A., Banister, D., 2018. Collaborative Backcasting for Transport Policy Scenario Building. Futures, Volume 95, pp. 11-21

Sotarauta, M., Kautonen, M., Lähteenmäki, T., 2002. Tulevaisuustiedosta kilpailuetua: Teknologian Ennakointikonsepti. SENTE-publication 14/2002. University of Tampere

Storper, M., 1997. The Regional World, Territorial Development in a Global Economy. Guilford Press/NY

Swart R.J., Raskin, P., Robinson, J., 2004. The Problem of the Future: Sustainability Science and Scenario Analysis. Global Environmental Change, Volume 14(2), pp. 137-146

Tay, M.Y., Rahman, A.A., Aziz, Y.A., Sidek, S., 2015. A Review on Drivers and Barriers towards Sustainable Supply Chain Practices. International Journal of Social Science and Humanity, Volume 5(10), pp. 892-897 
Teece, D., Pisano, G., Shuen, A., 1997. Dynamic Capabilities and Strategic Management. Strategic Management Journal, Volume 18(7), pp. 509-533

Teece, D., Pisano, G., 1994. The Dynamic Capabilities of Firms: An Introduction. Industrial and Corporate Change, Volume 3(3), pp. 537-556

Teece, D.J., 2000. Strategies for Managing Knowledge Assets: The Role of Firm Structure and Industrial Context. Long Range Planning, Volume 33(1), pp. 35-54

UNCTAD, 2018. Review of Maritime Transport. UNCTAD/RMT/2018. Available Online at https://unctad.org/system/files/official-document/rmt2018_en.pdf, Accessed on August 22, 2021

UNEP, 2021. United Nations Environmental Program. Why Does Global Clean Ports Matter. Available Online at https://www.unep.org/explore-topics/transport/what-wedo/global-clean-ports/why-does-global-clean-ports-matter, Accessed on August 25, 2021

Vergragt, P.J., Quist, J., 2011. Backcasting for Sustainability: Introduction to the Special Issue. Technological Forecasting \& Social Change, Elsevier Inc, New York

Wiek, A., Iwaniec, D., 2014. Quality Criteria for Visions and Visioning in Sustainability Science. Sustainability Science, Volume 9, pp. 497-512

Yashin, S., Yashina, N., Koshelev, E., Kashina, O., Pronchatova-Rubtsova, N., 2020. Foresight of Volga Federal District Innovation System Development using a Multi-Objective Genetic Algorithm. International Journal of Technology, Volume 11(6), pp. 1171-1180

Zahra, S., George, G., 2002. Absorptive Capacity: A Review, Reconceptualization, and Extension. The Academy of Management Review, Volume 27(2), pp. 185-203 